\title{
中国・湖南省における農家楽宿泊機能の実態と利用者評価 一株洲市市域を事例として一 \\ A STUDY ON THE ACCOMMODATION FUNCTION AND VISITORS' EVALUATION OF HAPPY FARMHOUSE IN HUNAN PROVINCE, CHINA
}

- A case study of town area of Zhuzhou city -

周星*，池田孝之**

\section{Sheng ZHOU and Takayuki IKEDA}

\begin{abstract}
In this study, firstly by gathering and analyzing previous studies, the development process of accommodation function of the livable Happy Farmhouse in Zhuzhou City was reviewed with its characteristics being summarized. Secondly, by practicing an on-spot investigation, the current situation of the livable happy farmhouse in this area was studied. Thirdly, by carrying out a consciousness survey of overnight visitors, views about the accommodation conditions in the Happy Farmhouse were collected. Based on the classification of the Happy Farmhouse and by analyzing the points of view from different visitor groups, charms and problems were determined. At the end of this paper, suggestions for the improvement of the living conditions in the Happy Farmhouse were discussed.
\end{abstract}

Keywords : China, Hunan, Happy Farmhouse, Accommodation, Overnight Visitor, Evaluation 中国, 湖南, 農家楽, 宿泊機能, 利用者, 評価

\section{1 はじめに}

\section{1 研究の背景と目的}

中国の観光業は 20 年近くの高度成長を経て、既に新しい段階注 1) に入ってきている。農村地域においては、都市との交流活動により 地域振興を図ろうとする取り組みが見られ、特に農家楽と呼ばれて いる農村に滞在する短期観光が注目されている。農家楽観光は、従 来のリゾート観光を主に海外レジャーの観光客を対象とするものに 対して、地域近くの来訪者を主要な利用対象とし、農村地域にある 歴史・自然資源や地場産業を観光業に結びつけている。

一般的に、農家楽は美しく、交通の便のよい都市近くの農村・郊 外に建てられ、ホテルと同じような客室を持ちながら、宿泊料はホ テルより低価格で利用でき、それにレストラン、カラオケ等の飲食・ 娛楽施設が完備され、さらに魚釣り場やゴルフ場等の特別な施設も 設けられ、観光も農業体験も娛楽も一箇所ですむようになった。こ のような魅力を持つため、農家楽の利用者がより増加してきている。 特に近年においては滞在する利用者が増える傾向が見られ、湖南省 株洲市農家楽では 2008 年に滞在する利用回数が 240 万回を超え、宿 泊及び関連サービスによる年間収入は 3 億元に上り、2005 年と比べ て50\%以上増えている ${ }^{1)}$ 。

筆者らは 2007 年株洲市農家楽の実態について調査し、農家楽の発 展経緯・現状を整理・分析した上で、その特徴を把握し、また、利 用者の意識調査と、経営者へのヒアリング調査によって農家楽の経 営効果・問題点・課題について考察した。前回の考察により、農村・
名所周辺にある農家楽に滞在する利用者が相対的に多いことを明ら かにし、短期滞在する利用者むけの宿泊機能の検討が必要になると 指摘した。しかしながら、前回の研究では滞在する利用者の滞在経 験や宿泊への評価を直接に尋祆ることはしておらず、農家楽の宿泊 機能について利用者の意識や志向等は未解明であった。従って、本 研究では、(1)農家楽の宿泊機能に着目し、その実態を明らかにする、 そして(2)宿泊先として利用された農家楽に対寸る宿泊客の評価を解 明し、宿泊可能な農家楽の魅力と抱える問題点を把握し、今後の農 家楽における宿泊機能向上ための方策について考察する。

\section{2 既往研究}

1995 年から 2005 年にかけての農家楽に関する研究は、農家楽の 発展原因や文化・経済意義に着目寸る基礎的な研究が多い。2005 年 からの農家楽に関する研究については、主に五つのグループ注 2)に 分けられる。(1)経営上の問題とその解決提案に関寸る研究は、王紅 らの「農家楽開発経営中存在的問題及解決途径(安徽農業科学、 2008. 8)」という研究論文があり、(2)サービスの定価研究は、舒䢐ら の「農家楽消費価格研究(価格与市場、2004.7)」との研究があり、(3) 季節変更による農家楽経営への影響に関する研究は、陈辉らが「休閑 農業走向討析 (西南民族学院学報、1998.4)」で考察した、(4)経営方式 のあり方の検討については、胡先群らが「農家楽旅遊対経済発展的作 用及文化意義一胆県農家旅遊調查 (中共成都党委学報、1999.4)」で論 述したが、(5)行政管理に関する研究は、楊継瑞らの研究論文「農家楽 健康発展的思考」(決策諮恂通迅、2004.8)がある。

\footnotetext{
* 琉球大学大学院 博士後期課程 $\cdot$ 農修

Graduate Student, Graduate School of Engineering and Science, University of the Ryukyus, M. Agr.

** 琉球大学工学部 教授・工博

Prof., Faculty of Engineering, University of the Ryukyus, Dr. Eng.
} 
本研究では、筆者らの研究論文の「中国・湖南省における農家楽の 利用事態に関する考察」2) に基づき、そこでの宿泊先であった農家楽 を現地調查の対象に抽出し、宿泊サービスを受けた利用者を意識調 查の対象として、農家楽の宿泊機能及び利用者の意識を探る。

\section{3 研究の方法}

(1)現地実態調査：調查対象地区は、農家楽観光活動が活発化して いる株洲市の五地区とする。平成 20 年 8 月 15 日から 9 月 25 日の間、 前回の調查した 89 箇所注 3 ) 農家楽のうち、農業経営に主軸を置き、 宿泊可能な農家楽の 44 箇所 (表 2) を抽出し、農家楽の立地特徵、宿 泊施設・設備、周辺の公共施設、サービス等について現地調查を行 った。調查地区の内訳は、石峰区雲田郷 6 䇢所、荷塘区仙㣎嶺の 10 箇所と、株洲県大京郷の 10 箇所、天元区馬家河鎮と群豊鎮の 12 箇 所、芦淞区曲尺郷 6 箇所である。

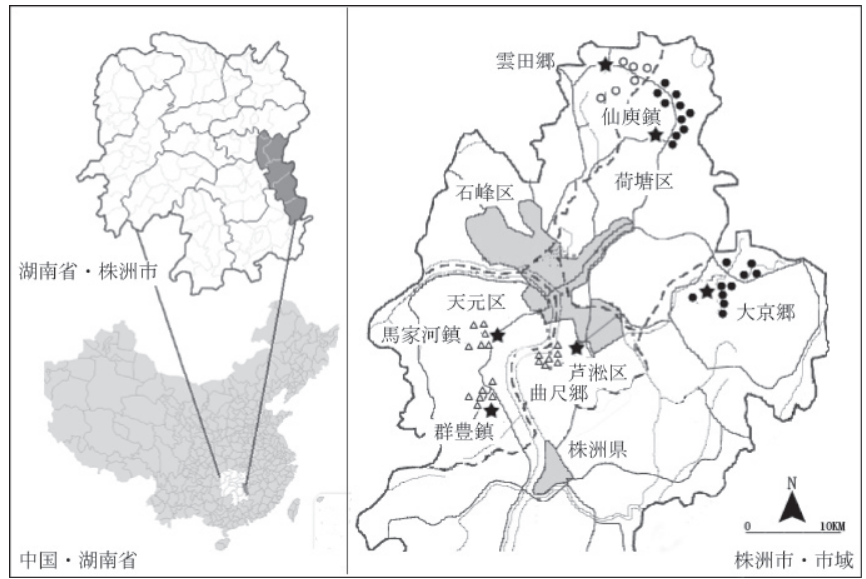

図 1 アンケート対象農家楽の位置注 4

*右の図については、 $\triangle$ は近郊農家楽で、○は農村農家楽で、のは名所農家楽である *灰色の部分は株洲市市域の中心市街地である

*星印は市域内五つ地区の地区政府の位置である

(2)来訪者意識調査 : 来訪者側の調査は、来訪者が滞在した農家楽 についての宿泊経験やサービスに対する満足度を調べた注5)。来訪者 の 1 グループごとに 2 枚の調查表を配布し、できる限り年齢・性別 の異なる 2 名の回答を求め、その結果は 162 グループ(全配布グルー プの 54\%) から 288 件 (全回収件の 56\%)の有効回答を得た。意識調査 では農家楽の立地、宿泊施設・設備等に対する利用者の意見を求め た。そして、来訪者からみた農家楽への満足度と問題点を観光、建 物・設備、ホスピタリティ、アクティビティ面から考察した。

\section{2 農家楽における宿泊機能}

農家楽は農村で良質な食品を食べ、歴史・自然・文化も体験でき、 利用者の心身のリフレッシュを図る観光である一方で、地域に住む 人々にとって販売や宿泊等サービスによる収益性があり、生活・文 化等を蓄積することができる経営方式と定義できる。80 年代から、 中国四川省を始めとして農家楽は急速に普及してきたが、1998 年に 中央政府による都市農村交流のキャンペーンをきっかけにし、農家 楽は全国へと爆発的に広がり、2000 年前後全国的に流行してきた。 湖南省では、90 年代後期に政府が制定した観光計画に応じ、大都市 近郊に農家楽が建てられ、次第に農村地域・都市内部へ発展した。 株洲市の農家楽は農家飯店に基づいて発展してきたものである。
1998 年、政府組織「観光産業発展グループ」の指導によって、株洲市 における観光産業の発展に伴い、多くの場所で農家飯店が建設され た。その後、市政府が提出した農村観光の構想に応じて多くの農家 飯店は農家楽に移行してきた。表 1 に示すように、2001 年以前、株 洲市では農業や林業等との兼業をしながら、飲食を中心とする農家 楽が多かった。宿泊施設については、既存家屋の改築程度で、設備 は家族と共用となっていた。このような農家楽を起業する費用が低 いため、経営者が全ての開業費用を負担していた。この段階では、 大規模の建設が少ないことから、農村における地域らしさが最も残 されていた。だが、誘客システムの不備のため、宿泊客が少なかっ た。2001年から農家楽の持ち主は農業組合や社会組織から融資を受 け始め、農家楽の増改築は流行になり、宿泊できる農家楽の数が大 幅に増えてきた。しかしながら、収容能力が高くなる一方で、設備 面とのアンバランスが目立つようになった。施設の使用不便や衛生、 安全問題への心配から、宿泊客の増える傾向がまだ見られなかった。

表 1 株洲市農家楽における宿泊機能の発展段階注 6$)$

\begin{tabular}{|c|c|c|c|c|}
\hline \multirow{2}{*}{$\begin{array}{l}\text { 時 } \\
\text { 間 }\end{array}$} & 第一段階 & 第二段階 & 第三段階 & 第四段階 \\
\hline & 90年代後期 & $2001 \sim 2003$ & $2003 \sim 2007$ & $2007 \sim$ \\
\hline $\begin{array}{l}\text { 建 } \\
\text { 物 } \\
\text { 設 } \\
\text { 備 }\end{array}$ & $\begin{array}{l}\text { 既存家屋の改築 } \\
\text { 程度、設備は家 } \\
\text { 族と共用で整っ } \\
\text { ていない }\end{array}$ & $\begin{array}{l}\text { 増改築が盛んに行わ } \\
\text { 几、収容力は大きく } \\
\text { なり、設備面とのア } \\
\text { ンバランスが立つ }\end{array}$ & $\begin{array}{l}\text { 増改築は一段落し、設 } \\
\text { 備も整い、宿泊できる } \\
\text { 農家楽、農村旅館、グ } \\
\text { リーンンホテル共存する } \\
\text { ところも現れる }\end{array}$ & $\begin{array}{l}\text { 宿泊できる農家楽では } \\
\text { 農家旅館、グリーンホ } \\
\text { テルと同等の建築、設 } \\
\text { 備を持つ }\end{array}$ \\
\hline 資 & $\begin{array}{l}\text { 投資額が低いた } \\
\text { 、経営者の家 } \\
\text { 族が負担する }\end{array}$ & $\begin{array}{l}\text { 組合や社会組織等か } \\
\text { ら融資を受け始める }\end{array}$ & $\begin{array}{l}\text { 農村信用合作社・農業 } \\
\text { 銀行から融資・貸し付 } \\
\text { けを受けられる }\end{array}$ & $\begin{array}{l}\text { 投資額が大きくなるた } \\
\text { 、借り入れだけで足 } \\
\text { りず、土地の売却や賃 } \\
\text { 貸しが行われる }\end{array}$ \\
\hline 特 & $\begin{array}{l}\text { 地域らしさを最 } \\
\text { も残す }\end{array}$ & $\begin{array}{l}\text { 宿泊できる農家楽の } \\
\text { 己造が流行になる }\end{array}$ & $\begin{array}{l}\text { 旅館的な外見を持った } \\
\text { 宸家楽が多くなった }\end{array}$ & $\begin{array}{l}\text { 農家楽、農村旅館、ホ } \\
\text { テルが混在している }\end{array}$ \\
\hline $\begin{array}{l}\text { 問 } \\
\text { 題 } \\
\text { 点 }\end{array}$ & $\begin{array}{l}\text { 誘客システム不 } \\
\text { 備で宿泊利用者 } \\
\text { が少ない }\end{array}$ & $\begin{array}{l}\text { オフ・シーズンの対 } \\
\text { 策を考えないと経営 } \\
\text { が苦しい }\end{array}$ & $\begin{array}{l}\text { 投資額が多くなり、施 } \\
\text { 設更新の資金に困る }\end{array}$ & $\begin{array}{l}\text { 競争は激しくなり、集 } \\
\text { 各が難しくなってくる }\end{array}$ \\
\hline 地暨 & なし & $\begin{array}{l}\text { 芦淞区曲尺郷、石峰 } \\
\text { 区雲田郷 }\end{array}$ & $\begin{array}{l}\text { 天元区馬家河鎮と群豊 } \\
\text { 真 }\end{array}$ & $\begin{array}{l}\text { 株洲県大京郷、荷塘区 } \\
\text { 仙庭嶺郷 }\end{array}$ \\
\hline \multirow{3}{*}{ 発 } & $\begin{array}{l}\text { 飲食を中心と者家一時的 } \\
\text { る農察人気とな }\end{array}$ & $\begin{array}{l}\text { 用地制限のため、こ } \\
\text { れ以上の発展できな } \\
\text { い。飲食を中心す } \\
\text { るところが多い }\end{array}$ & - & \multirow{3}{*}{ 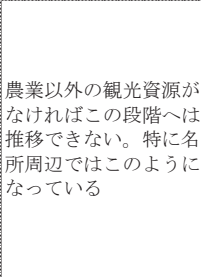 } \\
\hline & - & $\begin{array}{l}\text { 施設化に資金土地が } \\
\text { 必要で農業との両立 } \\
\text { は難しい }\end{array}$ & - & \\
\hline & - & - & $\begin{array}{l}\text { 施設化に資金土地が必 } \\
\text { 要で農業との両立は難 } \\
\text { しい }\end{array}$ & \\
\hline
\end{tabular}

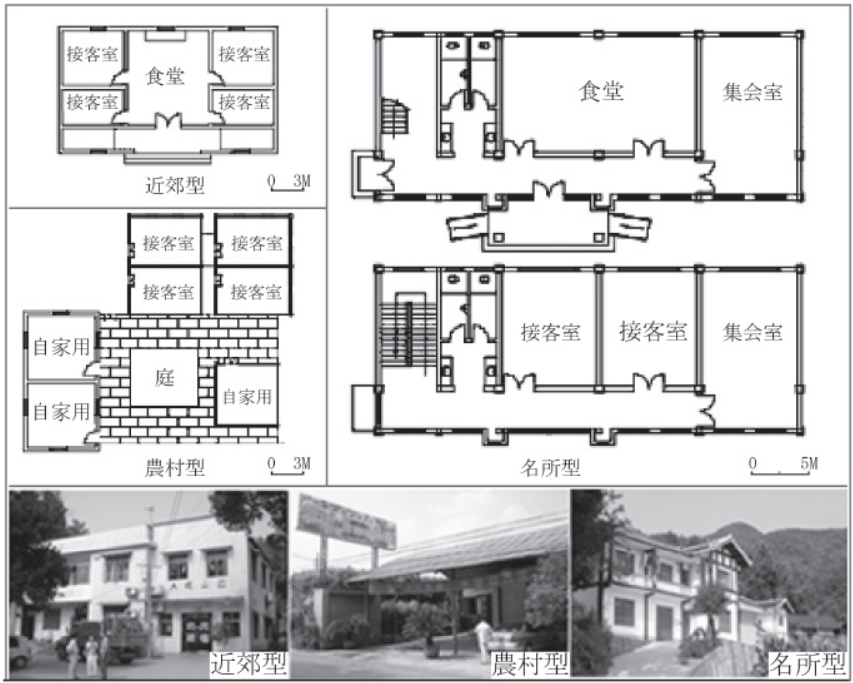

図 2 農家楽宿泊室の平面図注 7 
この段階では、経営者にとってオフシーズンに関する対策はますま 寸重要になってきた。2003 年から、一部の農家楽において飲食・宿 泊を専業するビジネスが始まり、多くの地区にはグリーンホテルや 農家旅館等が建てられた。集客への競争が激しくなったことから、 農家楽の施設面についても急速に改善してきた。だが、農家楽経営 への投資額が多くなり、施設建設するためにも資金・土地が必要と なるため、農業との両立は難しくなってきた。農業以外の観光資源 がなければ、宿泊できる農家楽の発展は非常に難しいとみられてい る。2007 年まで、株洲市大京郷等の名所周辺にはホテルと同じよう な建物・設備を持つ農家楽が発展してきたが、それ以外の多くの地 区では農家旅館の外見の規模が小さい農家楽が多かった。

来訪者が宿泊寸るための部屋は、農家の自宅の一室、あるいは昔 の農業用の空き部屋を改造したものが多かったが、近年から新築、 増・改築が流行になり、建築も欧米風や中国少数民族風注 8$)$ となり、 $\mathrm{RC}$ 造以外、 $\mathrm{CB}$ 造や木造や等様々な構造に発展してきた。その結果、 古い民家を転用寸るケースは僅かとなっている。また、来訪客のプ ライバシーや衛生面への配慮から、新築された建物は経営者の住宅 からだんだん離れつつある。株洲市では発展途上の農家楽に対して ホテルの基準を導入した注9) ため、現在農家楽における宿泊室はホテ ルのような洋室とする傾向がみられている。室内にある設備も新し く、テレビ、エアコンが付き、専用のトイレ、シャワー室も設けら れている。だが、ソフト面のサービスについては、家庭的で素朴な 接客方式は以前と変わらない。都市内部・近郊の農家楽は、建設用 地が取りにくいため、現在でも客の寝室を除き、レストラン・廊下・ シャワー室・トイレ等の部分を共用するケースが多い。

農家楽利用者の数は季節によって大幅に変わるため、長期的に雇 用された専門的な従業員は非常に少ない。一般的に、多くの従業員 は経営者の家族、あるいは地元の若者であり、大体一時雇用されて いる。しかし、従業員の専門性が足りないことで、緊急な事態に対 寸る対応不足や来訪者との交流がしにくい等の問題があった。従業 員のサービスレベルを向上させるため、2009 年から株洲市では農家 楽の従業員の雇用・処遇・就労環境に関寸る方針、各種制度の検討 を始め、管理職向けの従業員労務管理研修も実施した。

株洲市では宿泊可能な農家楽は旅行代理店と契約していないもの が多く、その理由としては、旅行代理店の契約に斡旋料がかかるこ

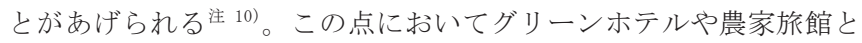
異なる。しかしながら、農家楽の利用者にとっては、旅行代理店と 契約のない農家楽の情報を得にくいという不便さがあった。

\section{3. 農家楽に関する実態調査}

\section{1 調査対象の概要}

調査した 44 箇所の農家楽を表 2 にまとめた。調査項目について、 ハード面においては農家楽の総面積、建築面積、別荘・客室の数、 内装のスタイル、駐車場の有無等を含め、ソフト面においては宿泊
設備の提供方式、一日あたりの出費、専門従業員の有無等となって いる。項目によって農家楽の合計を表 3 にまとめた。調查によると、 この 44 箇所の農家楽は市域の五区・県にあるが、全体からみると、 異なる場所であっても顕著な相違がなく、ここでは中心市街地から 離れた距離と農家楽の周辺環境特徴によって、調查したものを近郊、 農村、名所三つのタイプに分けた乼11)

近郊農家楽は芦淞区曲尺郷、天元区馬家河鎮と群豊鎮にあり、建 設用地が取りにくいため、経営者が自分の住宅を飲食・宿泊施設と して利用している。農村型農家楽は石峰区雲田郷にあり、都市の中 心市街地から少し離れているため、週末には来訪者が相対的に多か った。経営者は自宅を中心とし、近くには宿泊利用者のための建物 を増・改築し、周辺にある菜園、池、林地を活用しながら、来訪者 に対して多くのサービを提供できる。名所型の農家楽は荷塘区仙㣎 嶺と株洲県大京にあり、利用者のために新築した建物を中心とし、 周辺の菜園、果樹園、池等の農業資源、山、樹林等の自然資源を活 用寸るものである。長期休睱の利用者が多く、名所への足場として 利用されたケースが多かった注12)。

\section{1.1 宿泊室及び関連施設の提供}

\section{表 2 調査した宿泊できる農家楽のリスト注 13)}

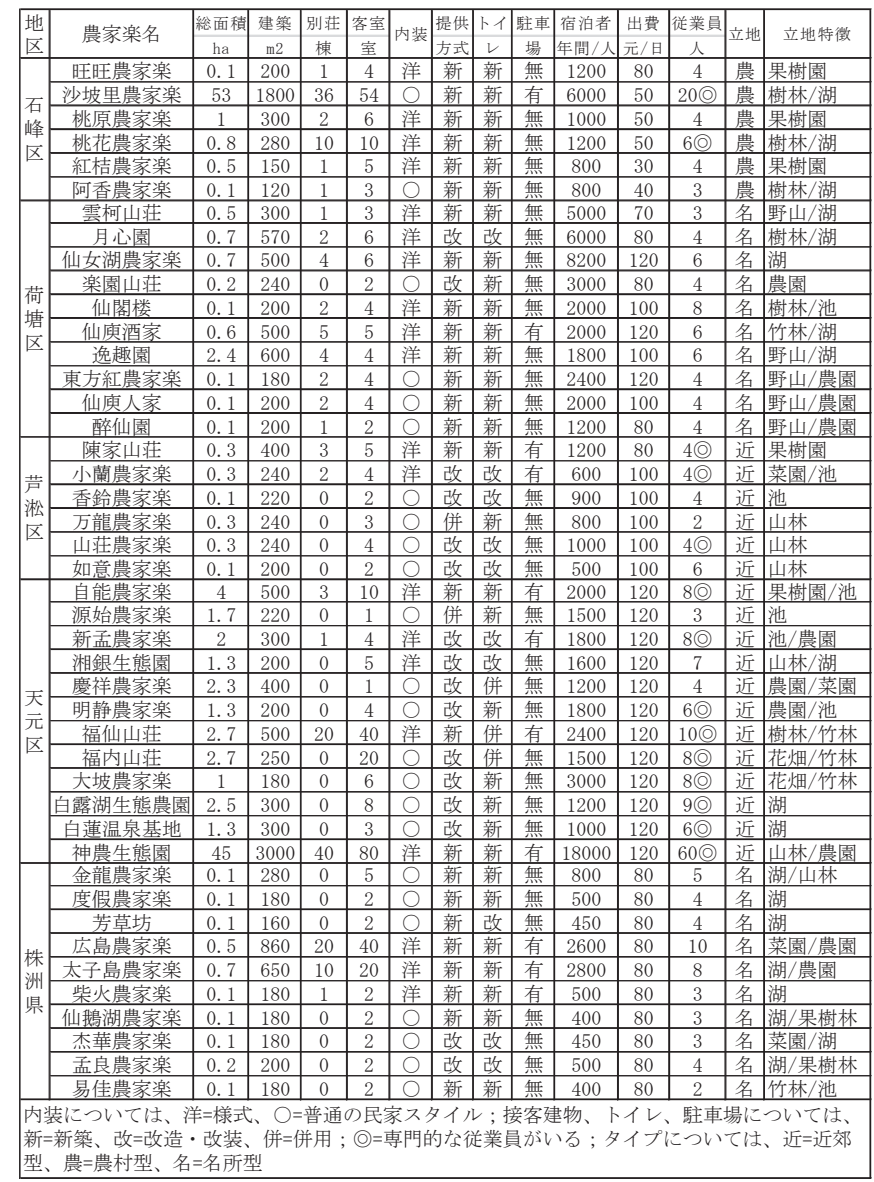

表 3 項目によって農家楽の合計

\begin{tabular}{|c|c|c|c|c|c|c|c|c|c|c|c|c|c|c|c|}
\hline \multirow{2}{*}{ 立地別 } & \multicolumn{3}{|c|}{ 接客室 } & \multicolumn{3}{|c|}{ トイレ・シャワー室 } & \multicolumn{2}{|c|}{ 駐車場 } & \multicolumn{3}{|c|}{$\begin{array}{c}\text { 宿泊料金(元·日) } \\
\end{array}$} & \multicolumn{2}{|c|}{ 専門的な従業員 } & \multicolumn{2}{|c|}{ 他のサービス } \\
\hline & 別荘新築 & 改良·改造 & 併用 & 新築 & 改良·改造 & 併用 & あり & なし & 50元未満 & $50 \sim 80$ 元 & 80元以上 & あり & な & あり & な \\
\hline & & $12(67 \%)$ & $2(11 \%)$ & $9(50 \%)$ & $6(33 \%)$ & $3(17 \%)$ & $6(33 \%)$ & $12(67 \%)$ & $2(11 \%)$ & & & $12(67 \%)$ & & & - \\
\hline & & & - & & & - & & & 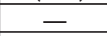 & & & $2(60 \%)$ & & & $=$ \\
\hline 名所型 & $16(80 \%)$ & $4(20 \%)$ & - & $16(80 \%)$ & $4(20 \%)$ & - & $4(25 \%)$ & $16(75 \%)$ & $=$ & & $6(30 \%)$ & - & $20(100 \%)$ & $8(40 \%)$ & $2(60 \%)$ \\
\hline$\overline{\bar{c}}+$ & $26(59 \%)$ & $16(36 \%)$ & $2(5 \%)$ & $31(70 \%)$ & & $3(7 \%)$ & . & & $(5 \%)$ & & & $4(32)$ & & & \\
\hline
\end{tabular}


表 3 によると、宿泊するための建物については、全体からみると、 新築、増・改築の割合が高かった。具体的に言えば、「宿泊客のため に貸し別荘を新築する」が 26 箇所 (59\%) を占め、一番多く、その次に 「自分の部屋か、以前の農業用の空き室を改良・改装する」が 16 箇所 (36\%) で、自分の部屋をそのまま併用寸る」が僅か 2 箇所 $(5 \%)$ となっ ている。タイプ別からみると、農村農家楽では全ての接客室が (6 箇 所) 新築され、名所型において新築されたものが 16 籄所 (80\%) とな っている。それに対して、近郊農家楽では新築されたもの僅か 4 箇 所 $(22 \%)$ であった。中心市街地から距離が遠くなると、新築と増・ 改造率が高くなる傾向が見られる。その理由は、農村・郊外では建 設未利用地が多いことがあげられる。しかしながら、農家楽の改造 に建設資金が必要なことから、名所周辺や農村地域において土地の 売却が盛んになり、地域の景観を大幅に変えてきている。

トイレ、シャワー室の衛生設備は、全体からみると、「客用のため 新設」が $70 \%$ と最も多く、次いで改良・改造」が $23 \%$ であり、「家族 用をそのまま使う」が 7\%であった。タイプ別からみると、農村・名 所型の新築率の高いことに対して、近郊農家楽の共用率は相対的に 高い。駐車場については、全体からみると、7 割の農家楽には駐車 場がなく、タイプ別みても同じ結果であった。「近くの空き地で止め てもいい」という意見が農家の経営者からよく聞こえた。

\subsection{2 宿泊料金・従業員・サービスについて}

1 泊の出費（表 3)によって調査した農家楽は三つのグループに分 けられる。1 泊には 80 元以上が $36 \%$ (16 箇所)を占め、50 元から 80 元未満が $59 \%$ (26 箇所)であり、50 元未満の場所が $5 \%$ (2 箇所) とな

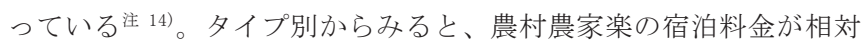
的に高いところが多く、80 元以上の場所が約 7 割となっている。そ の理由は、宿泊室は新築別荘であり、地域には他の宿泊施設が少な いことがあげられる。50 元から 80 元未満のグループについては、 料金が低い所は大体農家の自宅であり、一般的に室内にはベッドし かなく、他の整備も古い農家式であるが、昔の農家の雾囲気が最も 味わえるとも言われている。

この 44 箇所の農家楽全体からみると、専門的な従業員は約 3 割を 占め、主に近郊型と農村型農家楽に集中している。名所型農家楽に おいて専門的な従業員が居らず、その多くは経営者の家族、または 地元の若者であり、殆ど一時雇用されている。

農家楽におけるサービスは、近年からも多様化になってきている。 食事・レクリエーション以外には、以下のようなサービスが見られ てきている。(1)周辺地域一の交通案内・地図・アクセスの情報、(2) ファックス、コピー、カメラ・車のレンタル、(3)農産品の宅配便、 バイク便、(4)会社向けの多用途会議室のレンタル、ネットサービス 等。今回調查した農家楽は、近郊・農村のものにおいて全てこのよ うなサービスを提供し、名所農家楽では約 6 割が提供されている。

\subsection{3 飲食及び農業体験の提供}

食事の提供については、まず、「一泊二食提供する」が 91\%(40 箇所) であり、「一泊朝食提供」が $9 \%$ (4 箇所) であった。また、「一泊朝食 提供」としているところは名所農家楽に集中している。これは多くの 名所農家楽への宿泊利用者は名所への見学が目的であり、宿泊はそ のための足場としているからだと考えられる。全体からみると、欧 米のような自炊式食事を提供したところはない。

農業体験の提供については、すべての農家楽は室内のレクリエー
ションを提供し、主にカラオケ、マージャンがあり、他の活動につ いての種類は(1)四季青果の収穫、(2)農産物の加工、(3)室外のレクリ エーション、(4)自然散策・採集、(5)会社の会合・集会、(6)伝統文化 の体験となっている。全体から見れば、中心市街地から距離が遠け れば遠いほど、農業に関連する体験活動が多くなってくる傾向がう かがえる。特に名所型の農家楽において、名所への観光も盛んに行 われている。

\section{2 宿泊利用者の意識調査について}

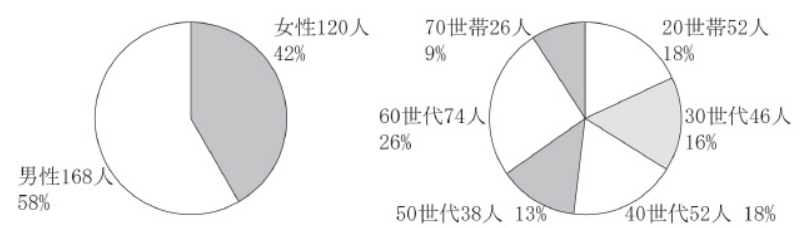

図 3 利用者の性別・年齢
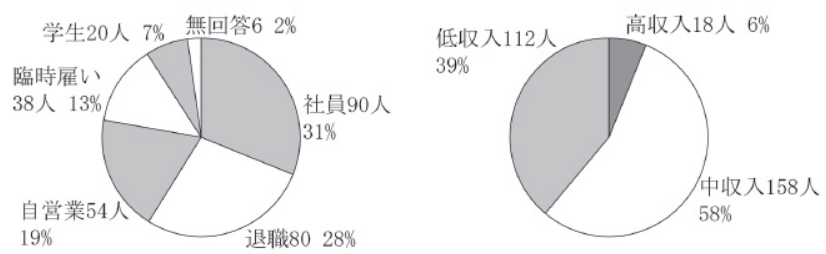

図4 利用者の職業・収入

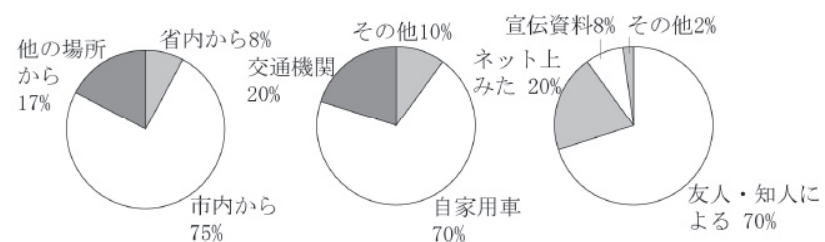

図 5 利用者の居住地・交通手段・情報源

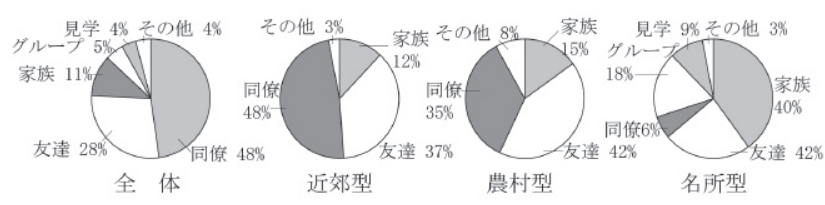

図 6 利用者グループの性格

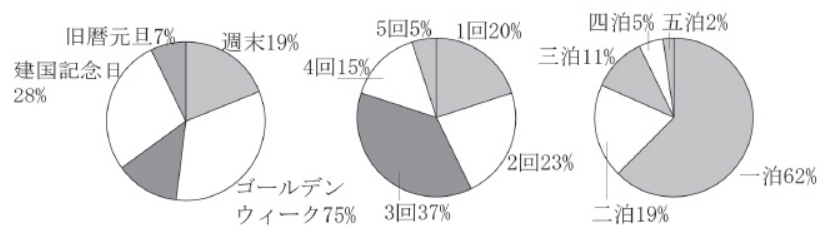

図 7 利用者の来訪時間 $\cdot$ 利用回数 $\cdot$ 方式

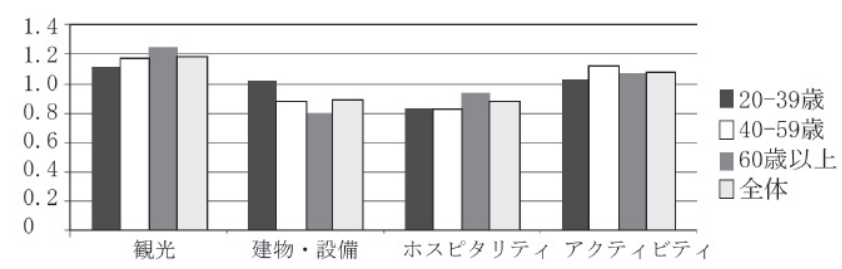

図 8 宿泊先選定に関する要因 


\section{2.1 宿泊利用者の属性}

\section{(1)利用者の性別・年齢}

宿泊利用者は、男性 58\%(168)、女性 42\%(120) となっている。年齢 別からみると、60世代が 26\%(74) と最も多く、40世代と 20 世代い ずれも $18 \%$ (52)を占め、30 世代が 16\%(46)、50 世代が $13 \%$ (38)、 70 世代が 9\%(26) となっている。

\section{(2)利用者の職業・収入}

利用者の職業からみると、会社員 31\% (90)、退職した方 $28 \%(80) 、$ 自営業 19\%(54)、臨時雇い $13 \%$ (38)、学生 7\%(20)、その他 2\%(6) とな っている。社員がやや多い原因は、農家楽を会社の短期研修・会議 の集合場として利用する傾向があるためである。

来訪者の収入については、 $55 \%$ (158)の来訪者が中収入者であり、 39\%(112) が低収入であったが、僅か 6\% (18) が高収入者となっている。 宿泊利用者は主に中低収入の人々であることが分かった。

\section{(3)利用者の居住地・交通手段・情報入手源}

75\%(218)の利用者が株洲市市民で、17\%(48) が省内の別の都市から きており、僅か $8 \%(22)$ が省外からきた。これらの現状は「農家楽観 光において近くの来訪者を利用対象とすること」と一致している。

交通手段については、自動車の利用者が $75 \%$ (216) を占め、公共交 通機関が 17\%(48)、その他が 8\%(24) となっている。「滞在している間 に、自家用車を持つと便利」、「公共交通が極めて少ない」、地域内 部の移動は難しい」という意見がよく聞こえた。

宿泊先の情報入手源については、「友達、知人が紹介してくれた」 70\%(202)、「インターネットの掲示板からみた」20\% (58)、「ガイドブ ックやパンフレットによる」10\%(28)であった。宿泊に関する情報を 主にロコミによって得られたとわかった。

\section{(4)利用者グループの性格}

全体からみると、同僚と一緒に利用する宿泊者が最も多い、 $48 \%$ を占め、次に友達と利用するのが $38 \%$ となり、家族と利用するのが $19 \%$ でった。家族より仕事仲間や友人と利用寸る特徵がうかがえる。

タイプ別からみると、自然の雰囲気が相対的に強い農村・名所型 農家楽においては、家族での宿泊利用者が増え、同僚・友達とで利
用者が減る傾向がみられる。これはグループの性格によって利用者 のニーズが変わるためだと考えられる。家族利用者はより自然・農 業を味わうことを重視しているが、同僚・友達との利用者は相対的 にレクリエーションに集中している。

\section{(5)利用時間 $\cdot$ 頻度 $\cdot$ 方式}

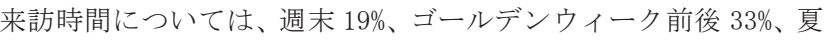
休み $13 \%$ 、建国記念日の休み $28 \%$ 、旧暦元旦の休み $7 \%$ となっている。 長い休暇に宿泊来訪者が多い傾向がみられる。

業務関係での宿泊を除き、宿泊を伴う農家楽利用について、1 年 間あたり平均 2.6 回で、 1 回あたりの平均 1.7 泊となり、旅行回数 の多い来訪者の方が 1 回あたりの宿泊数も多い傾向がうかがえる。

\section{2.2 宿泊利用者の意識調査}

\section{(1)宿泊先の選定について}

宿泊先を選定する際に、利用者は農家楽のどのような面について 期待しているのかを調査した。まず、農家楽の定義によって宿泊先 の要素を「観光」、「建物・設備」、「ホスピタリティ」、「アクティビテ イ」に分類し、そして、来訪者を「20～39 歳まで」、「40～59 歳まで」、 $「 60$ 歳以上」にグループ化した。また、分類した要素に対して来訪者 の評価を重視程度によって、「全然期待していないを「-2 点」とし、 「期待してない」を「-1点」とし、「どっちでもない」を「0 点」とし、「や や期待している」を「+1 点」とし、「大変期待している」を「+2 点」とし、 年齢グループの人数によって農家楽宿泊先への期待を数值化した。

図 8 で示した通り、来訪者が以上 4 つの要素への期待はいずれも 0.8 以上の期待度を示している。全体からみると、最も高いのは「観 光」の 1.18 であり、これは農家楽の宿泊先に対する利用者の全体イ メージとしては、豊かな自然や美しい景色等がみられることである ため、当然の結果だと思われる。次に「アクティビティ」に対する期 待度がやや高く、1.07 であった。年齢別からみると、年齢が増える ほど、「観光」への期待が高まり、「建物・設備」に対する重視程度が 低くなる特徴がうかがえる。また、「60 歳以上」のグループにとって、 「ホスピタリティ」に対する重視程度も相対的に高い特徵がみられ、 これは高齢者自身の特徵に対応しているものだと考えられる。
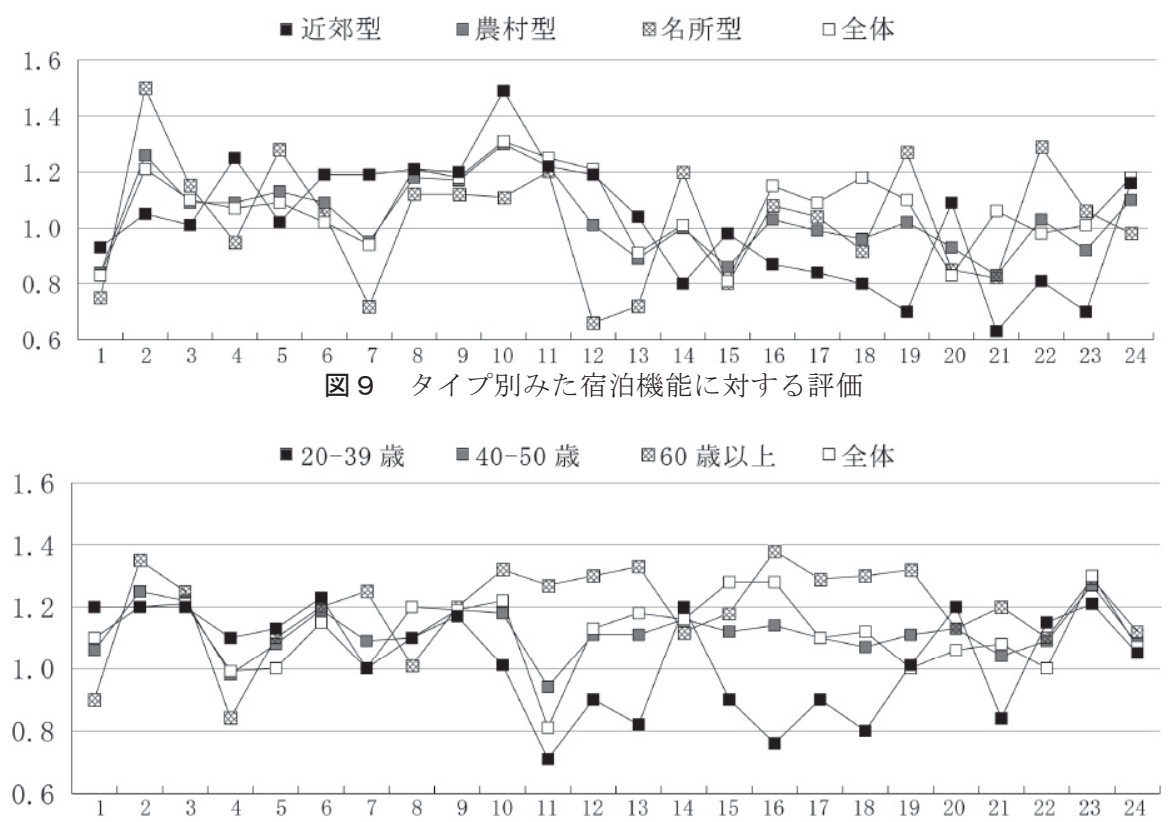

\begin{tabular}{|c|c|}
\hline 1 & 位置の環境立地 \\
\hline 2 & 自然的な環境立地 \\
\hline 3 & 社会的な環境立地 \\
\hline 4 & 交通の環境立地 \\
\hline 5 & 宿泊建物の外観 \\
\hline 6 & 宿泊室の内装 \\
\hline 7 & 食堂・レストラン \\
\hline 8 & トイレ・シャワー室 \\
\hline 9 & 冷暖房 \\
\hline 10 & 誛具 \\
\hline 11 & 従業員の気配り \\
\hline 12 & 経黨者との交流 \\
\hline 13 & 地域人々との交流 \\
\hline 14 & プライバシーの保護 \\
\hline 15 & サービス \\
\hline 16 & 農産物収穫体験 \\
\hline 17 & 食品加工 \\
\hline 18 & 農作業体験 \\
\hline 19 & 室外レクリエーション \\
\hline 20 & 室内レクリエーション \\
\hline 21 & グラフイック体験 \\
\hline 22 & 観光地巡 \\
\hline 23 & 散策・ハイキング \\
\hline 24 & 部屋にのんびりする \\
\hline
\end{tabular}

図 10 年齢別からみた宿泊機能に対する評価 


\section{(2)宿泊機能に対する評価}

ここでは利用者による宿泊機能についての評価を探る。宿泊機能 への評価に関与寸る要因は、農家楽の立地環境特徵や、「建物・設備」、 「ホスピタリティ」性、「アクティビティ」等は重要な項目だと考えら れる。この調査では、まず、立地特徴を「位置的な環境」、「自然的な 環境」、「社会的な環境」、「交通的な環境」に分け、「建物・設備」、「木 スピタリティ」、「アクティビティ」についても細かく分類した注 ${ }^{15)}$ 。 そして、宿泊客が分類した要素に対する評価を「大変満足」から「大変 不満」までに対応して得点 $「+2 」$ から「-2」まで 1 点の間隔尺度とし、宿 泊者回答数によって平均值が得られた。

年齢別にみた来訪者評価の結果については(図 10)、40～59 歳の回 答者の評価は全回答者の結果と近い傾向がみられる。立地特徵に対 して、60 歳以上の利用者は農家楽の「位置の環境立地」(0.90) と「交 通の環境立地」(0.84) に対する評価が低かった。また、「従業員の気 配り」、「経営者との交流」、地域人々との交流」、「サービス」、「ア クティビティ」の多くの項目に対し、20３9 歳の若い利用者の低い 評価に対して、60 歳以上の方からの評価が高いことがみられた。こ れらのことは、利用者の年齢階層によって宿泊機能に関わる項目に 対する重視レベルが変わることを示している。

立地特徵については (図 9)、近郊型農家楽の「交通的な環境」 (1.25) と、農村 - 名所型農家楽の「自然的環境」 $(1.21 、 1.50)$ に対寸 る評価が高かった。内部の「建物・設備」「ホスピタリティ」、「アク ティビティ」については、近郊型農家楽の「客室内装」(1.19)、「食堂・ レストラン」(1.19)、「寝具」(1.49) 等に対する評価は相対的に高く、 農村農家楽において「アクティビティ」の多くの項目に対する評価が 高かった。名所型農家楽において、建築の外観 (1.28)、プライバシ 一の保護 (1.2)、室外レクリエーション (1.27)、観光地巡り (1.29) 等への評価は高かったが、食堂・レストラン $(0.72)$ 、経営者との交 流(0.66)、地域の人々との交流(0.71) への満足度が著しく低かった。 これらのことから、農家楽立地特徵や内部条件によって利用者の評 価も、問題点も異なり、宿泊機能を向上寸るためには、農家楽の夕 イプ別に対応することが必要だと考えられる。

\section{(3)利便施設に対する評価と理由}

ここでは利便施設の充実を中心とする宿泊機能の評価を見る。宿 泊に関わっている利便施設は、主に公共公益施設、食料品販売施設、 日用品販売施設、医療・福祉施設、文化・教育施設、污水・ゴミ処 理施設があげられる。このような項目に対して利用者の意見を求め、 得点は宿泊機能に関する評価と同じような方法で算出した。

全体からみると (図 11) 、「医療・福祉施設」(0.52)、「文化・教育 施設」(0.52)、「污水・ゴミ処理施設」(0.50) に関する得点が相対的に 低かった。これらは農家楽の経営において利用者の直接のニーズに 着目し、宿泊機能を支える基盤についてはそれほど重視していない ことを示している。タイプ別にみると、近郊農家楽の「公共公益施設」 (1.42)、「食品販売施設」(1.20)、「日用品施設」(1.16) についての得 点が高がったが、都市からの距離が増えると、多くの項目への評価 が低くなっている。最も低いのは名所農家楽の「医療・福祉施設」に 対寸る評価であり、僅か 0.32 である。主な不満の理由は図 12 に示 している。特に「営業時間が短い、「数が少ない」、「住む場所から遠 い」があげられた。日常的によく利用する施設については、立地・サ 一ビスの便利さや、值段の安さと共に求められていることが推測さ
れる。以上のことから、宿泊機能に関する要因として、利便施設も 利用者の評価として重要であることが示された。

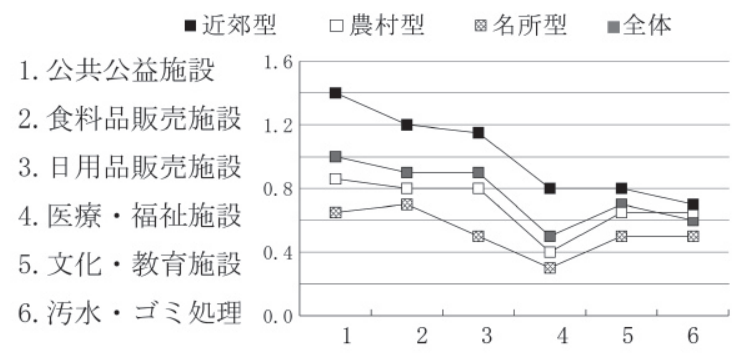

図 11 利便施設に対する評価

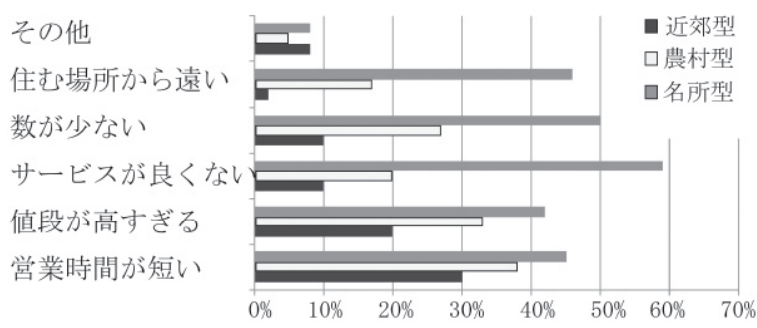

図 12 利便施設に対する不満の理由

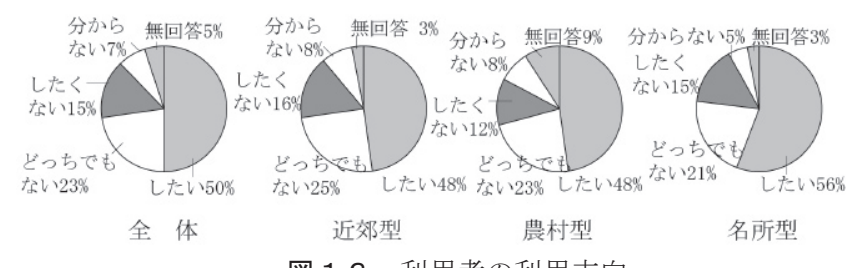

図 13 利用者の利用志向

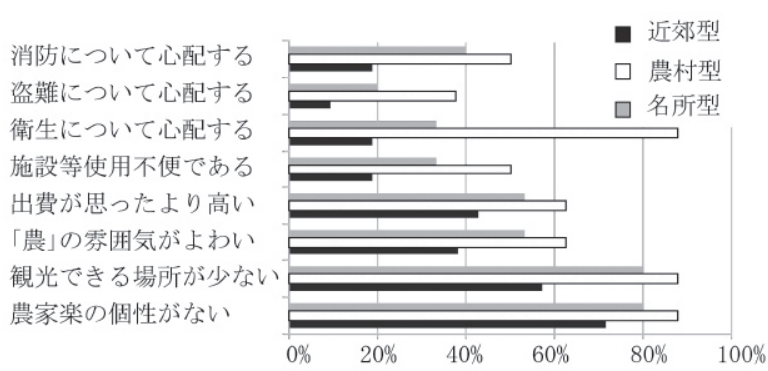

図14 利用したくない理由と要望

消防について心配する 盗難について心配する 衛生について心配する 施設等使用不便である 出費が思ったより高い 「農」の雾囲気がよわい 観光できる場所が少ない 農家楽の個性がない

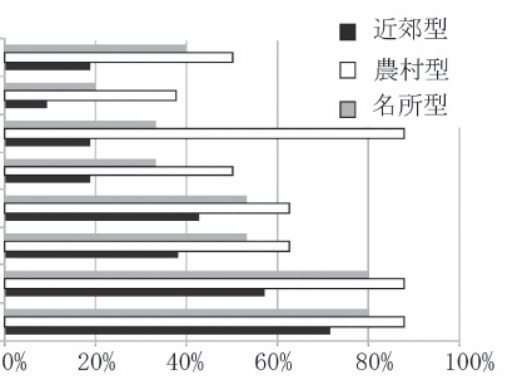

図 15 利用者の要望 


\section{(4)宿泊への利用志向・要望}

来訪者の利用意向については(図 13)、全体からみると、「行程・ 時間の余裕によって泊ってみたい」という回答が約半分を占める。利 用したくない理由をみると（図 14）、「宿泊先の個性がなく、建物か らアクティビティまで全て似ている」、「観光できる場所が少ない」、 「農村の特徴が失われつつある」、「衛生・盗難・消防等への心配があ る」等となっている。これらの問題は、農村にある農業・自然資源等 の活用が低迷していることと、基本的なインフラ施設が遅れている ことから生じていると思われる。タイプ別からみると、名所型農家 楽の「利用したい」の回答比率が最も高く、56\%を占めており、これは 名所農家楽が自然の豊かさと建築外観の良さを持つ、観光地巡りが できることと関わっているためと考えられる。一方、「利用したくな い回答率の高い近郊農家楽については、農家の雾囲気が弱い、観光 資源の不足、農業に関連するアクティビティも少ないことが主な原 因であると推測される。ここでは宿泊利用者の要望についても尋ね た(図 15)。「周辺の散歩・ハイキングできる場所」、「気軽に観光が できる場所」、「農産物収穫体験教室」、「農産物加工教室」、「クラフ 卜体験教室」、地区人々との交流できる場所」等を望む割合が相対的 に高い。設備の改善と施設の充実を進めつつも、農村にある自然・ 農業の魅力を維持・活用することがより強く望まれていると言える。

\section{(5)宿泊に関する自由意見}

表 4 自由意見の分類

\begin{tabular}{|c|c|c|c|}
\hline 番号 & 項 目 & 数 & 割合 \\
\hline 1 & 農家楽の内部環境（駐車場、集会室、緑、建物外観等） & 47 & $22 \%$ \\
\hline 2 & 宿泊先の立地（農家楽への交通・公共施設等） & 36 & $17 \%$ \\
\hline 3 & 宿泊建物・客室の内部条件（間取り、設備、騒音問題等） & 32 & $15 \%$ \\
\hline 4 & 全体の満足に関する意見 & 28 & $13 \%$ \\
\hline 5 & 管理、運営 & 24 & $11 \%$ \\
\hline 6 & 宿泊するための出費 & 23 & $11 \%$ \\
\hline 7 & その他 & 21 & $10 \%$ \\
\hline \multicolumn{2}{r|}{ 合計 } & 211 & $100 \%$ \\
\hline
\end{tabular}

表 5 利用者の自由意見

\begin{tabular}{|c|c|c|}
\hline \multicolumn{2}{|c|}{ 項目 } & 具体的に意見 \\
\hline & 便利性 & $\begin{array}{l}\text { (1)農家楽に関する情報が取得しにくく、改善してほしい。(2)農村への道には交通標識が少な } \\
\text { いため、たずねにくい。(3)農村への道が狭く、舗装は悪い。 }\end{array}$ \\
\hline & 要望 & (1)市内の路線バスを農家楽に延ばしてほしい。(2)道等を整備してほしい。 \\
\hline \multirow{9}{*}{$\begin{array}{l}\text { 農 } \\
\text { 家 } \\
\text { 楽 } \\
\text { 内 } \\
\text { 部 } \\
\text { 環 } \\
\text { 境 }\end{array}$} & 全体的 $1=$ & $\begin{array}{l}\text { 1)自然の雲囲気が感じられるが、文化的に不毛の地となった感じをする。(2)飲食・レクリ } \\
\text { エーションセンー感じが強い。(3)「俗世界から離れられる」という感じはまたくしな } \\
\text { い。(4)自然への配慮が足りなく、農業資源の利用程度が低い。 }\end{array}$ \\
\hline & 建築 & 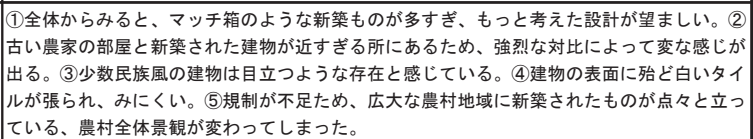 \\
\hline & 客室 & 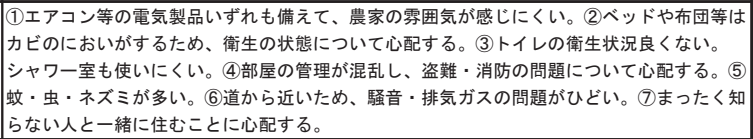 \\
\hline & 集会室 & 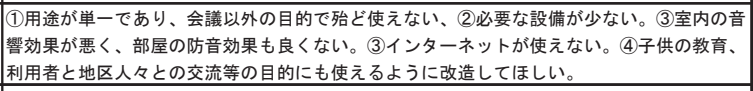 \\
\hline & 駐車場 & $\begin{array}{l}\text { (1)数が少ない。(2)夜間の照明・安全対策が悪い。(3)狭い所でのユーターンもできない。(4)利 } \\
\text { 用者ための駐車場があってほしい。 }\end{array}$ \\
\hline & 緑 & 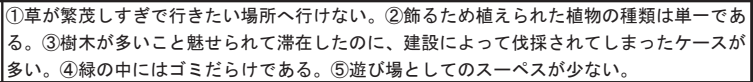 \\
\hline & 料金 & (1)宿泊を支えるための出費は思ったより高すぎる。(2)一部の別荘の料金が高い。 \\
\hline & 体験 & $\begin{array}{l}\text { (1)他の場との活動が類似しているため、新鮮感がない。(2)地域の人々との交流のチャンスが } \\
\text { とれない。(3)供を教育するための体験活動が少ない。(4)農業に関連する活動が少ない。 }\end{array}$ \\
\hline & 要望 & $\begin{array}{l}\text { (1)自炊があってほしい。(2)農村にある自然・古い農家建物等を残してほしい。(3)地元の文 } \\
\text { 化・歴史を活用することが望ましい。(4)旧家の立派な大黒柱や梁を含めて伝統的な農家建築 } \\
\text { を残してほしい。 }\end{array}$ \\
\hline
\end{tabular}

表 4 は、来訪者の中の 72 人から得られた 211 件の自由意見であり、 ように、まず、これらの意見を「立地」と「内部環境」に二つのクルー 7 グループに分けられている。分かりやすくするため、表 5 に示す プに分類し、また、「内部環境」については、「建物・設備」、「ホスピ タリティ」、アクティビティ」の方面からそれぞれの問題をまとめて いる。

宿泊先の立地と言えば、「情報源が足りないこと」と、「行く道には 標識が不足や、道の幅が狭く、路面条件が良くないこと」等を問題と してあげられる。特に立地に関して利用者が「路線バスで行けたら良 いとの要望があった。この点については、農家楽への交通機関を設 ければ、利用者がさらに増えると考えられる。「内部環境」に関する 意見から見ると、宿泊先の全体に対して、利用者から「文化的な不毛 の地と感じられ」、飲食・レクリエーションセンターとなっている」、 「自然への配慮がたりなく、農業資源の利用程度が低い」等の意見が 得られた。詳しい項目に関する意見は、主に駐車場、集会室、緑、 利便施設に集中している。「専用の駐車場の数が足りない一方で、照 明・安全対策が悪い」、「集会室には必要なものがなく、用途が単一 で、他の用途も実現できればいい」、「植物が繁茂しているため、行 きたいところに行けない」、飾るため植えられた植物が少ない」、建 設によって大きな木を伐採してしまう」となっている。

その他には、建物外観の設計、接客室の整備、体験できる活動の 欠如、騒音・照明等の意見が得られた。特に、「マッチのような建物 が多すぎ」、新築されたものと元の建物との調和感がとれていない」、 「少数民族風のものが目立つような存在と感じている」等の意見が得 られた。これらは、農家楽の開発における全体規制の不足によって 生じ問題だと考えられる。利用要望としては、「自炊があってほしい」、 「伝統的な古い農家建物が残されて欲しい等の意見があった。

\section{4. まとめ}

（1）(1)農家楽の宿泊機能は、利用者が短期滞在できる一方で、農 村観光・農業体験を通して地元の人々との交流といった活動を付加 する宿泊形態にあり、家族による観光や会社の研修・集会等の多岐 に涉る利用ニーズに対応している。(2)株洲市の場合には、農家楽の 宿泊機能は 2003 年から大きく発展し、接客設備や施設が急速に改善 されてきている。しかしながら、近郊・農村農家楽においては、施 設を建設するための資金・土地を必要とすることから、農業との両 立が困難となっている。名所農家楽においては、名所地を特別な資 源として利用できるため、宿泊機能が大幅に発展し、ホテルのよう な建物・設備を持つようになった。

（2）宿泊利用者は、近くの地域から、自家用車を利用する会社員 や、退職した人々を中心とした中低収入者が多いのが特徴である。 グループの性格からみると、近郊・農村農家楽への利用者は職場の 同僚・友人での利用する割合が高いが、名所農家楽への利用者は家 族での利用する割合が高い。長い休暇に宿泊利用寸る傾向がある。

(3) (1)農家楽の宿泊機能の魅力は、全体的に「観光」と「アクティビ ティ」の二項目があげられる。年齢別からみると、若者は「建物・設 備」に魅力を感じているが、高齢者にとって「ホスピタリティ」性を 魅力に感じている。(2)宿泊機能に対する評価については、近郊農家 楽の「交通的な環境」と、「設備・施設」における多くの項目への評価 と、農村・名所農家楽の「自然的な環境」、農業体験・室外活動等に 
対する評価が高いが、近郊農家楽の農業体験活動に関わる項目への 評価は低い。これらの結果は、農家楽の立地特徵を活用したことに よるものであり、当然な結果だと考えられる。(3)年齢階層からみる と、利用者は農家楽の「ホスピタリティ」性、「アクティビティ」の多 くの項目に対する評価が著しく異なる。高齢者は農業体験や交流活 動に対する評価は高いが、若者の評価が低い。利用者の年齢階層の 特徵に応じてサービスを提供することが求められると考えられる。

(4) (1)宿泊機能を支える利便施設についての評価は、都市部から 遠くなると評価が低下寸る傾向が見られる。その理由としては、施 設の立地の不便さや、サービス質の低下、料金の高いことがあげら れる。特に名所農家楽においては、医療・福祉施設、文化・教育施 設の増加が求められていると考えられる。(2)利用志向からみると、 利用者の半分以上を超えて、続けて利用したい農家楽は名所型のみ となっている。利用したくない理由は、宿泊先の特徴がなく、観光 できる場所が少なく、出費が高い等となり、また、衛生・盗難・消 防への不安もある。これらの問題は、宿泊先にある自然・農業資源 の活用が十分にできないことと、宿泊機能を支える交通手段や利便 施設のインフラ施設が遅れていることから生じると考えられる。

（5）宿泊機能を向上するために、利用者の要望と意見に速やかに 対応し、農家楽の内部環境や利便施設を整備し、地元にある自然資 源の魅力を活かしながら、専門的な人材を充実させることが必要だ と考えられる。可能な限りに宿泊先の周辺には自然との親しむ空間 をつくり、近郊農家楽では農業体験活動を増やし、近郊・名所農家 楽では交流活動を促進することによって利用者がさらに増加すると 考えられる。これからの農家楽事業においては、顕在化されていな い農村にある文化・歴史・農業価值を見つけ出すことも必要であり、 また、各農家楽間の協力関係を構築し、それぞれの長所を活かして 良好な機能を補完しあうことも重要であると考えられる。

\section{謝辞}

本研究を進めるにあたって、株洲市観光局、株洲市商務局、株 洲市地方税務局、株洲市天元区城市管理行政執法局の方々から、多 くのご指導とご指導をいただき、ここに記して感謝致します。

\section{注}

注1）新しい階段と言えば、王文亮が執筆した「中国観光業詳説」によると、(1) 新たなインフラ整備を中心とすることから、現有インフラ施設を再利 用・経済効果の向上を中心とすることへの転換、(2)観光資源の簡単開 発・利用から、資源の再認識・総合利用への転換、(3)単一サービス経営 から、本業を中心としての多角経営への転換、(4)従来の数量追及型の経 営から、経済効果を重視する経営一の転換、といら四特徴があげられる。

注2） 2005 年からの農家楽に関する研究の分類は、CNKI という学術論文検索 システムで論文主題別によって検索結果であった。CNKI (China National Knowledge Infrastructure)のデータベースには中国大陸にお ける発行された学術雑誌や新聞、学位論文、会議記録が収録されている。

注3）この 89 箇所の農家楽については、2007 年 8 月から 9 月までの間に、日 帰り利用者を含めて利用者の評価を把握寸るために調查した。今回の調 查は、主に宿泊機能に関わる項目の利用実態を考察するため、宿泊でき る場所と宿泊利用者に限定して実施した。

注4）記号については、メ、○、はそれぞれ近郊型、農村型、名所型農家楽 を表している。灰色の部分は株洲市の中心市街地であり、星印は地区政 府の位置を表している。

注5）宿泊利用者の意識調查は、株洲市天元区城市管理行政執法局の方々の協 力を求め、2007 年調查した 89 箇所の農家楽のうち、4 4 箇所宿泊できる 農家楽を選定し、調査表を農家楽の経営者に預计、定期的に回収・補充
して実施した。2008 年 8 月 15 日から 2009 年 7 月 15 日かけて 300 グル 一プから 512 枚調查表を回収した。本調査は、宿泊機能に関寸る来訪者 の意識を解明することであるため、日帰り利用者は調查対象から除いた

注6）株洲市観光局が編集した「株洲市観光十年」による。図には農家旅館とい う言葉が記載されている。農家旅館は、明確的に定義されていないため、 農家楽との区分は曖昧である。の二つのものに関する区別については、 学者が「規模が比較的に大きく、客室等の設備が主に洋式であるものが 農村旅館とされ、小規模で客室が伝統的な農家設備を備えるものが農家 楽とされ、特に食事については、農家楽の場合には料理に用いる食材は 農業・漁業・畜産経営等から直接に調達している場合が多いが、農村旅 館では使う食材を購入するのが普通である」と指摘している。

注7）名所型農家楽の平面図は一般的な 2 階の借り別荘であり、その中には 経営者が住んでいる部分は入っていない。

注8）漢族以外には、湖南省では土家族、苗族、瑶族、白族、回族、壮族等 多くの少数民族がある。農村観光を契機に、少数民族部屋のスタイル や生活習慣、民間風俗、農業行事等を観光対象として省内に広がり、 観光の人気ものとなっている。

注9）参考文献 2 によ。2000 年前後農家楽宿泊機能を誘導するため、株洲 では多くの農家楽においてホテルのようなサービス・施設を導入した。 注10）株洲市観光局が編集した「株洲市観光十年」(内部資料)による。

注11）分類基淮は陳蕾らが執筆した「浅析農家楽的興亡和発展」（四川経済管 理学院学報、2004. 3) による。農家楽の分類に関寸る基準が多くあり、 例えば、農家楽の周辺環境特徴によって「水郷」、「花郷」、「竹郷」農家 楽等に分け、地域の性格によって「近郊」、「農村」農家楽に分け、消費 方式によって「一次性消費」と「即時消費」に分類し、農家楽の主題によ って「現代農家型」、「田園風光型」、「民俗体験型」に分け、建築スタイ ルによって「古典園林式」「現代園林式」「欧米建築式」に分けている。 だが、多くの農家楽における周辺環境や、建築スタイル等には顕著的 に相違がないため、中心市街地から離れた距離と環境特徴により、近 郊・農村・名所農家楽に分けられている。

注12）参考文献 2 による。

注13）表記については、洋は「様式」、新は「新築」、改は「改装・改造」、併は「併 用」、○は「専門的な従業員がいる」のを示している。タイプの近・農・ 名はそれぞれ「近郊」・「農村」・「名所」農家楽を指している。

注14） 2005 年株洲市観光局が実施した観光調查によると、50 元・80 元は市 民の「安い、「普通」、高い上と見分ける判断基淮である。

注15）農家楽の立地特徴は、都市から離れた距離によって異なるが、比較し やすくするため、文献によって農家楽の立地を「位置的」「自然的」、「社 会的」「「交通的」環境に分けている。宿泊するための内部環境には、「宿 泊の場」、飲食の場」、社交的な場」、「観光・娛楽・レジャーの場」、 「休息の場」「「ビジネス活動の場」等があるが、ここでは宿泊先を選択 する理由に対応して考察するため、内部環境を「建物・設備」「ホスピ タリティ」性、「アクティビティ」に三グループ分類した。具体的に言え ば、「建物・設備」には「建物の外観」、「客室の内装」「食堂・レストラ ン」、「冷暖房」、「寝具」等を含め、「ホスピタリティ」には「経営者や従 業員の気配り」、「経営者・従業員との交流」、地域人々との交流」、「プ ライバシー保護」、「サービス」等を含め、「アクティビティ」には「農産 物収穫体験」、食品加工」、「農作業体験」、「アウトドアのレクリエー ション」、「室内レクリエーション」、「クラフト体験」、「観光地巡り」、 「散策・ハイキング」、「何もしなくてのんびりする」等を含んでいる。

\section{参考文献}

1）中国湖南省旅遊統計年鑑編集委員会 : 湖南旅行統計年鑑 2008

2）周戟，池田孝之：中国・湖南省における農家楽の利用実態に関する考 察，日本建築学会計画系論文集，Vol. 73, No. 632, pp2139～2146, 2008. 10

3）去石真佐子, 藤崎浩幸 : 農家民宿に対寸る意識調査, 農村計画論文集, No. 2, pp283 288, 2000. 12

4）中島正裕，千賀裕太郎，斎藤雪彦：農村地域における観光資源に対す る来訪者の評価分析, 農村計画学会誌, Vol.20, No. 3, 2001. 12

5）劉娅娅，柏原士朗，吉村英祐，横田隆司，飯田匡：公的賃貸集合住宅 団地の立地・住み環境に対する住民評価, 日本建築学会計画系論文集, No. $581, \quad p p 1 \sim 8,2004.7$

6）高田哲也，佐藤洋平，石川雅也：北海道におけるファームインの現状 と評価, 農村計画論文集, Vol. 2, pp289～294, 2001. 12

7）白澤恵一：民宿立地論，渓水社, $\mathrm{pp} 23 \sim 25$ 